\title{
THE ANALYSIS OF VIOLATING MAXIM ON SAPA INDONESIA MALAM TELEVISION NEWS PROGRAM TOWARD THE EPISODE 'TUDINGAN KONSPIRASI DIBALIK KORONA'
}

\author{
${ }^{1}$ Atikah Wati, ${ }^{2}$ Indra Nabila Zahra \\ Universitas Wiralodra \\ E-mail: ${ }^{1}$ Atikah_wati@unwir.ac.id, ${ }^{2}$ indranabilazahra99@gmail.com
}

\begin{abstract}
When interacting with other people, we must cooperate during the conversation. By cooperating, it will make the conversation run well and flow smoothly. However, the speaker can violate the maxim and caused understanding. This study aims to analyze violating maxims done by a speaker on "Sapa Indonesia Malam" news program that consists of two segments. The writers analyze the data by applying the theory of cooperative principle by Grice and using descriptive qualitative method. The result of this study showed that there are sixty-four violating utterances. Relation maxim comes as the most common maxim that violating by the speaker. It occurs twenty-eight times during the conversation. After that, it was followed by quality maxim with twenty-one violation utterances. Then ten times of violation quantity maxim and maxim of manner as the lowest violation because it only occurs five times.
\end{abstract}

Keywords: Cooperative principle, violation maxim, a news program.

\begin{abstract}
Abstrak
Saat berinteraksi dengan orang lain, penting bagi kita untuk bersikap kooperatif selama percakapan. Dengan bersikap kooperatif, itu akan membuat percakapan berjalan dengan baik dan lancar. Namun, mungkin bagi pembicara untuk melanggar maksim dan menyebabkan pemahaman. Penelitian ini bertujuan untuk menganalisis pelanggaran maksim yang dilakukan oleh pembicara pada program "Sapa Indonesia Malam"yang terdiri dari dua segmen. Penulis menganalisis data dengan menerapkan teori prinsip kerja sama oleh Grice dan menggunakan metode deskriptif kualitatif. Hasil penelitian ini menunjukkan bahwa ada 64 pelanggaran ucapan. Maksim relasi datang sebagai maksim yang paling sering dilanggar oleh pembicara. Itu terjadi dua puluh delapan kali selama percakapan. Setelah itu diikuti oleh maksim kualitas dengan dua puluh satu ucapan pelanggaran. Kemudian sepuluh kali pelanggaran maksim kuantitas dan maksim cara sebagai pelanggaran terendah karena hanya terjadi lima kali.
\end{abstract}

Kata Kunci: Prinsip Kooperatif, Pelanggaran Maksim, Program Berita 


\section{INTRODUCTION}

Communication is the necessary foundation of human relationship and cannot separate from human existence. Through communication, a human can express their ideas and exchange information. According to Anggrarini (2007), communication becomes matters in our life because it is a way of exchanging information, this means of thinking, understanding, and expressing thought and feeling in the community. There are many ways in delivering the information, such as verbally (by voice), textually (by newspaper, books, magazines, or websites), and visually (by picture, video, graphs, and charts). In order to create successful communication, the speaker and the hearer should cooperate, so the communication will run well and flow smoothly.

One of the ways of being cooperated is by applying the Cooperative Principle (CP). Cooperative principle is a universal rule to portray the participants how they cooperate in conversation to gain efficient interaction (Levinson
1983: 101). Beside of that, according to Paltridge (2006), by following the cooperative principle, it will avoid some misunderstanding. Thus, by applying the Cooperative Principle, it is expected that the speaker and hearer will deliver information clearly and make their communication run efficiently and effectively. In addition, Yule (2006) proposed a cooperative principle to control the conversation between speaker and hearer that exchange information in their talk.

According to Grice (1975: 45), cooperative principle consists of four maxims (maxim of quantity, the maxim of quality, the maxim of relation and maxim of manner). However, people still deliberately do not obey and break these maxims. Grice (1989: 28) state that when the speaker does not fulfil or obey the maxims, the speaker is said to violate the maxims. Violating the maxims can happen when the speaker provide information less or more than what is required, and also when the speaker gives false information to the hearer without the hearer realize it. Speaker does violate the maxim because of 
many reasons, but one thing for sure that it can lead to misunderstanding. Leech (1983) argues that violation of conversational maxim takes place when the speaker fails to apply absolute maxim in the conversation to cause misunderstanding on their participant.

Sapa Indonesia Malam is one of a television news program that broadcasted by Kompas $T V$. In the Episode 'Tudingan Dibalik Konspirasi Korona', this program invited Jerinx and Hermawan Saputra as interviewees to discuss that topic with Aiman Witjaksono as the presenter of that program. Corona or COVID 19 become one of the trending topics worldwide lately due to its outbreak. The discussion of this episode gets lots of attention from many Indonesian citizens. The guests did many violation maxims when being interviewed by the presenter during the discussion.

Many studies have been conducted previously related to violation of this cooperative principle. Nur (2018), found the most frequent violations occurred when she analyzed the dialogue of "The
Wild Duck" by Henrik Ibsen is quantity maxim then followed by the quality maxim, relation maxim, and violation of manner maxim. Then, Toda \& Ghozali (2017) found that there are two patterns of maxims violations, namely violation one maxim and more than one maxims. Their research also provides several reasons why the characters in Maleficent Movie violate the maxims such as for hiding the truth, saving face, avoiding discussion, expressing feelings, pleasing the hearer, avoid punishment, and the last is to building someone's belief. In addition, Alfina \& Subiyanto (2016), in their finding, explain that another motivation behind the speakers violating the maxim is because mostly they want to show politeness and keep other's self-esteem. Although all of those studies were analyzed violation maxim, not many of those studies that focus on violation maxims in the television news program, moreover, information that delivered through television can be accessed easily by the audiences. Hence, it is vital to do not absorb all of the information 
delivered to us. Therefore, in this study, the writer focuses on the study of violation maxim on television news program 'Sapa Indonesia Malam'. The purpose of this study is to identify violation maxim done by the speakers in 'Sapa Indonesia Malam' television program and find the most dominant violating maxim.

\section{Cooperative Principle}

In order to build successful communication, speakers should apply some approaches during the interaction. Cooperative principle is a way in which people try to make conversations work. In participating in an interaction, Grice assumed that participants observe the following principle:

Make your conversational contribution such as is required, at the stage at which it occurs, by the accepted purpose or direction of the talk exchange in which you are engaged (Grice, 1989 [1967]: 26).

Grice broke down this general principle into a number of subprinciples, which he referred to as maxims, as follows:

\section{A. Quantity}

1) Make your contribution as informative as is required (for the current purposes of the exchange).

2) Do not make your contribution more informative than is required.

B. Quality

1) Do not say what you believe to be false.

2) Do not say that for which you lack adequate evidence.

C. Relation

1) Be relevant.

D. Manner

1) Avoid obscurity of expression.

2) Avoid ambiguity.

3) Be brief (avoid unnecessary prolixity [verbosity]).

4) Be orderly.

\section{The Violation of Maxim of Cooperative Principle}

Speaker and hearer do not always obey the cooperative principle during their conversation. They may fail in fulfilling a maxim in various ways and caused in violating the maxims. Violation the maxim takes place when speakers 
intentionally refrain from applying certain maxims in their conversation to cause misunderstanding on their participants' part or to achieve some other purposes (Grice, 1975). These following points are some causes when someone is violating maxim.

A. He may quietly and unostentatiously violate a maxim; if so, in some cases, he will be liable to mislead.

B. He may opt-out from the operation both of the maxim and of the CP; he may say, indicate, or allow it to become plain that he is unwilling to cooperate in the way the maxim requires. He may say, for example, I cannot say more; my lips are sealed.

C. He may be faced with a clash: He may be unable, for example, to fulfil the first maxim quantity (Be as informative as is required) without violating the second maxim of Quality (Have adequate evidence for what you say.)

D. He may flout a maxim; that is, he may blatantly fail to fulfil it. On the assumption that the speaker can fulfil the maxim and do so without violating another maxim (because of a clash), is not opting out, and is not, because of the blatancy of his performance, trying to mislead, the hearer is faced with a minor problem: how can his saying what he did say be reconciled with the supposition that he is observing the overall CP.

The following are examples of violation in the four aforementioned maxims from Khosarvizadeh and Sadehvandi (2011).

\section{1) Violating Quantity Maxim}

John: Where have you been? I searched everywhere for you during the past three months!

Mike: I wasn't around. So, what's the big deal? John poses a question, which he needs to be answered by Mike.

What Mike says in return does not lack the truth, however, is still insufficient. This can be because Mike prefers to refrain from providing John with the answer. John's sentence implies 
that Mike has not been around; otherwise, he did not have to search everywhere. John does not say as much as it is necessary to make his contribution cooperative. Hence, he leaves his listener unsatisfied.

\section{2) Violating Quality Maxim}

Mother : Did you study all day long?

Son : Yes, I've been studying till know! (While he has been playing all day long)

In this exchange, the boy is not truthful and violates the maxim of quality. He is lies to avoid unpleasant consequences such as; punishment or to be forced to study for the rest of the day.

\section{3) Violating Maxim of Relation}

Teacher : Why didn't you do your homework?

Student : May I go and get some water? I'm so thirsty.

In the above exchange, the student's answer is by no means relevant to the teacher's question. One reason for this answer can be the fact that the student is trying to evade the interrogation posed by the teacher.

\section{4) Violating Maxim of Manner}

Sarah : Did you enjoy the party last night?

Anna : There was plenty of oriental food on the table, lots of flowers all over the place, people hanging around chatting with each other...

Sara asked a very simple question, however what she receives from Anna is a protracted description of what was going on at the party. Two interpretations can be made from Anna's description: 1. Anna had such a good time at the party that she is too excited and has no idea where to begin. 2. Anna had such a terrible time, and she does not know how to complain about it.

In addition, the example, as mentioned above, can also be a case of multiple violations. Multiple violations occur when the speaker violates more than one maxim simultaneously. In this example, Anna is not only 
ambiguous (violating the maxim of manner) but also verbose (violating the maxim of quantity) at the same time.

\section{METHOD}

The writer used descriptive qualitative method. According to Mcnabb (2011), descriptive research deals with document pattern which will be analyzed and also involves gathering data that describe events and then the data will be organized, tabulated, depicted, and described. Furthermore, Aditya (2009) assumes that descriptive research tends to describe a phenomenon or individual characteristic, situation, particular group accurately. Data of this study was taken from 'Sapa Indonesia Malam' television news program that broadcasted on Mei $6^{\text {th }}, 2020$. The reason to choose this video is that this episode got much attention from the viewers. Moreover, the topic on that day was something that many people talked about nowadays.
In collecting the data, the writer firstly searched the video on https://www.youtube.com/user/Kom pasTVNews. Then the writer took the episode 'Tudingan Konspirasi Dibalik Korona' that consists of two segments. And then, the video transcribed the conversation into written form. After that, it classified into several types of violation maxim based on Grice's theory of Cooperative Principle.

\section{FINDING AND DISCUSSION}

\section{Finding}

The data of this research have been collected and analyzed by the writer. From the data, the writer found 64 violation maxims during the discussion. The type of violation maxim that found used by the speakers are a violation of quantity maxim, violation of quality maxim, violation of relation maxim, and violation of manner maxim. 
Table 1 The Result of Violation Maxim

\begin{tabular}{|c|c|c|c|}
\hline No. & $\begin{array}{c}\text { Types of Violation } \\
\text { Maxim }\end{array}$ & Frequency & $\begin{array}{c}\text { Percentage } \\
(\boldsymbol{\%})\end{array}$ \\
\hline 1. & Quantity & 10 & $15.6 \%$ \\
\hline 2. & Quality & 21 & $32.8 \%$ \\
\hline 3. & Relation & 28 & $43.8 \%$ \\
\hline 4. & Manner & 5 & $7.8 \%$ \\
\hline \multicolumn{2}{r|}{ Total } & 64 & $100 \%$ \\
\hline
\end{tabular}

From the table above, it shows that in two segments 'Sapa Indonesia Malam' news program, there are 64 violating maxims found in the analysis of the study. The violation consists of 28 relation maxim $(43 \%)$ as the most dominant violation that used by the speakers, then followed by quality maxim with 21 frequent (32.8\%), 15.6\% quantity maxim or ten utterances, and the last is five maxim of manner (7.8). Furthermore, there are two types of pattern found in this violation maxim study used by the speakers. The types are a violation of one maxim and violation of more than one maxim. Violation of more than one maxim happens when the speaker deliberately breaks some maxims within an utterance.

\section{Discussion}

In the episode of Conspiracy behind Corona, the writer found many violation maxims that have been done by speakers. The violation consists of a violation of one maxim and violation of more than one maxim. The following example shows violation maxim that has been done by interviewees.

\section{Conversation 1}

Aiman : "Anda belum menjawab saya Bung jerinx. 99\% anda katakana sembuh corona, penyakit corona 99\% sembuh. Itu data dari mana?'

Jerinx : "Jika anda tidak berusia, jika anda tidak berusia diatas 60-an, dan anda tidak anda tidak memiliki penyakit bawaan. Anda akan sembuh. Buktinya sudah banyak banget pasien yang sudah sembuh.' 
In this conversation, the presenter asked the interviewee where he got the data that $99 \%$ of people who have been infected by the Corona virus will be recover and only $1 \%$ death. Unfortunately, Jerinx cannot explain the source of the data, but he replied if you were not 60 years old and you do not have congenital diseases, then you will be recover. His answer is violating the maxim of relation because his answer was not relevant to what being asked by the presenter about the source of the data.

\section{Conversation 2}

Aiman: "Oke, di London di California Rumah Sakit sepi?"

Jerinx: "Ya."

In this conversation, Jerinx was being asked by Aiman related his statement that all hospitals in abroad was quiet and had no Covid19 patients. Jerinx's answer was violating maxim of quality because his answer was lack of adequate evidence.

\section{Conversation 3}

\section{Aiman: "Hmm tapi bukan Noam} Chomsky ya. Eee konstruksi realitas. Tapi saya ingin bertanya sederhana sesungguhnya. Dimana konspirasi covid 19 yang and tudingkan? Sesederhana itu."

Jerinx: "Ya konspirasinya adalah banyaknya angka yang tidak sebenar-nya, permainan angka jumlah korban. Salah satu saksinya, saksi nyata kru drum saya namanya Rizwan. Dia alergi makan cumi saya ajak makan cumi di Ubud ya eee sekitar minggu lalu saya ajak makan cumi di rumahnya Wayan Gendo, teman saya di Ubud. Lalu dia pertama kali makan seafood. Tidak pernah makan seafood seumur hidupnya, besoknya dia alergi, diajak ke rumah sakit eee ke rumah sakit saya lupa namanya. Dia di SWAB test. Masuk akal gak? Orang alergi cumi di SWAB test. Dia harus bayar 850 ribu. Dan banyak dokter di Amarika sudah banyak bersuara, dokter dokter di Amerika sudah banyak bersuara. Dan rumah sakit rumah sakit di Amerika dibayar untuk menaikkan angka jumlah korban. Jadi dokter-dokter dijanjikan eee apa namanya, bayaran jika mereka memberikan di sertifikat kematian tuh sebagai korban covid. Meskipun penyebabnya bukan covid.” 
In this conversation, Aiman and Jerinx talked about the conspiracy behind the corona. When Aiman asked in which part is the conspiracy that pointed by Jerinx, but Jerinx's answer violating two maxims at the same time. When Jerinx answered that his band member got allergy due to eating seafood and got SWAB test in the hospital, he violating the maxim of relation because deliberately change the topic related to the conspiracy that being asked to him, moreover, when he answered that many hospital and Americans doctors were promising of being paid more to increase the data of positive coronavirus cases and create COVID certificate to those who died without got infected to the virus, he violates the maxim of quality. It is because he was saying something without any evidence and spreading hoax.

\section{CONCLUSION}

Based on the findings above, the writer found many violation maxims of cooperative principle that have been done by the speaker such as violation maxim of quantity, maxim of quality, maxim of relation, and maxim of manner. The speakers sometimes violated one maxim on their utterance, and also violated more than one maxim at the same time. Sixty-four violation maxims occur in that news program. Violation maxim of relation was the highest violation done by the speakers. It occurred 28 times. They were then followed by violation of quality maxim, which occurs 21 times. And then, there were ten times of a violation of quantity maxim. The last, violation of manner maxim which occurs 5 times as the lowest.

From this study, the writers encourage the reader also to do a study related to cooperative principle and especially in violating the maxim. It is interesting to analyze the violation maxim because it can sharpen our critical thinking. Furthermore, the writers expect this study will give benefit to many people. 


\section{REFERENCES}

Aditya, S Dodiet. (2009). "Penelitian deskriptif". Retrieved:

September 2012.

Alfina, E. O., \& Subiyanto, A. (2016). The Maxim Violation on Mata Najwa Talk Show 'Selebriti Pengganda Simpati'. English Department Faculty of Humanities Diponegoro University Semarang.

Anggrarini, N. (2017). Conversational Implicature Analysis of Text Message Between Native Speaker and Foreign Language Speaker of English. WEJ (Vol. 1, No. 1)

Ghozali, I., \& Toda, M. A. E. (2017). Violations of Maxims Analysis of Cooperative Principle In Maleficent Movie. JELLT.

Grice, H. P. (1989). Logic and conversation. In Grice, H. P. (Ed.) Studies in the Way of Words (pp. 22-40). Cambridge, MA: Harvard University Press.

Grice, H.P. (1975). Logic and Conversation. In P. Cole \& J. Morgan (Eds), Syntax \& Semantics 3: Speech acts (pp.4-5). New York: Academic Press.
Khosravizadeh, P \& Sadehvandi, N. (2011). Some instances of violations and flouting of the maxim of quantity by the main character (Barry and Tim) in Dinner for schmucks, IPEDR (Vol. 26) Singapore: IACSIT Press.

Leech, Geoffrey. (1983). Principles of Pragmatics. London : Longman

Levinson, C. S. (1983). Pragmatics. London: Cambridge University Press.

McNabb, Conni. (2011). "Descriptive Research Methodologies." Retrieved: Sept 2012.

Nur, M. U. (2018). Violation of Grice's Cooperative Principle on The Dialogue of "The Wild Duck" by Henrik Ibsen. Journal of Research on Applied Linguistics Language and Language Teaching (Vol. 2, No. 1).

Paltriadge, Brian. (2006). Discourse Analysis: An Introduction. London: MPG Books.

Yule, G. (2006). The study of Language. New York: Cambridge University Press 